\title{
Nitzschia fenestralis: A new diatom species abundant in the Holocene sediments of an eastern African crater lake
}

\author{
David Grady ${ }^{1, *}$, David G. MANN ${ }^{2,3} \&$ Rosa Trobajo ${ }^{3}$ \\ ${ }^{1}$ Department of Geography and Earth Sciences, Aberystwyth University, Aberystwyth, SY23 3DB, Wales; \\ *Corresponding author e-mail: gradydai524@gmail.com \\ ${ }^{2}$ Royal Botanic Garden Edinburgh, Edinburgh, EH3 5LR, Scotland \\ ${ }^{3}$ Marine and Continental Waters, Institute for Food and Agricultural Research and Technology (IRTA), Crta de \\ Poble Nou Km 5.5, Sant Carles de la Ràpita, Catalonia, Spain
}

\begin{abstract}
Nitzschia is common in the phytoplankton of several East African lakes. A new species, Nitzschia fenestralis, sp. nov. D. Grady, D.G. Mann et Trobajo was encountered at numerous depths in a $16 \mathrm{~m}$ sediment core from Lake Babogaya, Ethiopia and is described using light and scanning electron microscopy. It is compared with several other morphologically similar taxa described from East and Central Africa (especially N. aequalis, $N$. mediocris, $N$. obsoleta and $N$. fabiennejansseniana), and from Europe ( $N$. fruticosa). An unusual feature of some of these species ( $N$. fenestralis, $N$. obsoleta and $N$. fabiennejansseniana) is that in the raphe canal each stria is represented by two narrower areolae (alternatively interpreted as a single subdivided areola). It is this feature that suggested the name of the new species (through the resemblance to a series of sash windows). Another characteristic of $N$. fenestralis and $N$. obsoleta, apparently never reported previously in any diatom, is that the more advalvar bands end approximately halfway along the frustules, rather than at the poles. In most respects (shape and size, stria and fibula densities, valve and girdle structure), $N$. fenestralis and $N$. obsoleta are very similar, but confusion is unlikely because they differ in whether central raphe endings are present ( $N$. fenestralis) or absent ( $N$. obsoleta). In Nitzschia fenestralis, and perhaps to a lesser extent in N. obsoleta, the striae usually become strongly radiate towards the poles. A preliminary assessment, based on the literature, suggests that $N$. fabiennejansseniana may be synonymous with $N$. obsoleta, which was described earlier.
\end{abstract}

Key words: Africa, girdle structure, Lake Babogaya, morphology, new species, Nitzschia, plankton, taxonomy

\section{INTRODUCTION}

Lake sedimentary archives have long been recognized, and regularly used, as the principal source of information in reconstructing the past climate and environments of tropical Africa (VERSCHUREN 2003). The focus of these reconstructions has varied from long-term glacial-interglacial dynamics through the Quaternary, to short-term centennial to inter-annual scales in order to understand the regional responses to natural shifts in climate; these reconstructions are relevant to current anthropogenic climate change and the role of climate in the development and evolution of humans through time.

Since it is not possible to make direct measurements of past environments, palaeoenvironmental proxies are needed and several characteristics of diatoms make them particularly useful. Their utility in understanding and reconstructing environmental conditions in arid and semi-arid environments has been outlined by GASSE et al. (1997). Warmer, tropical waters facilitate plankton communities rich in Nitzschia spp., unlike the waters of temperate and polar regions (RICHARDSON 1968; KILHAM et al. 1986). The abundance of Nitzschia in modern eastern African assemblages is well documented from surveys in lakes Kivu (SARMENTo et al. 2006), Victoria (KLING et al. 2001; Stager et al. 2009) and Tanganyika (COCQUYT \& VyVERMAN 2005), and more generally across the continent (GASSE 1986; Mills \& RYves 2012). Their importance has also been documented in fossil assemblages. For example, high abundances of Nitzschia spp. have been a feature in the flora of Lake Victoria for 10,000-11,400 years (STAGER et al. 1997; 2003) and for the past 25,000 years in Lake Challa (MiLne 2007; WolfF et al. 2014).

Nitzschia generally lack many distinguishing features, with their close morphological similarities making them notoriously difficult to accurately identify under the light microscope (LM). However, extensive scanning electron microscope (SEM) work on many taxa (e.g. references in Trobajo et al. 2013) have revealed 
multiple delicate morphological features not visible under LM that are useful in identifying and categorizing Nitzschia species. Thus, for example, use of SEM has facilitated the descriptions of several new Nitzschia species from lakes Victoria (SiTOKI et al. 2013) and Challa (CocQuYT \& RYKen 2017).

Recent palaeolimnological analyses conducted at an eastern African crater lake, Lake Babogaya (GRADY et al. in prep.), have revealed another example of Nitzschia dominance $(100 \%$ of total diatom abundance in some samples) in assemblages through the last 5,000 years of the Holocene. During these analyses, an abundant taxon ( $>50 \%$ abundance in several samples; see results) was observed throughout the record that does not exactly match any previously described Nitzschia species, though it resembles a number of species described from Africa and elsewhere by Hustedt $(1949,1957)$. In order to establish the taxonomy of the Babogaya specimens, they were studied in detail by light and scanning electron microscopy (LM and SEM) and compared with the type material of selected other, morphologically similar taxa. The aims of this paper are to: 1) describe a new species, Nitzschia fenestralis, from Lake Babogaya; (2) highlight how it differs from similar Nitzschia species; (3) comment on the temporal and spatial occurrence of $N$. fenestralis; and (4) highlight particularly unusual features of the new species, including any that may suggest which other species are its closest relatives. In order to help establish how $N$. fenestralis differs from other similar species, we borrowed type material of $N$. obsoleta Hustedt, $N$. aequalis, $N$. mediocris and $N$. fruticosa. However, although the results of these analyses update the original works of HuSTEDT (1949) and SimONSEN (1987) and may be useful for further studies related to the identification of problematic Nitzschia taxa, it was not our aim to make a full analysis of these species, which will require much further study. We give the formal description of $N$. fenestralis at the beginning

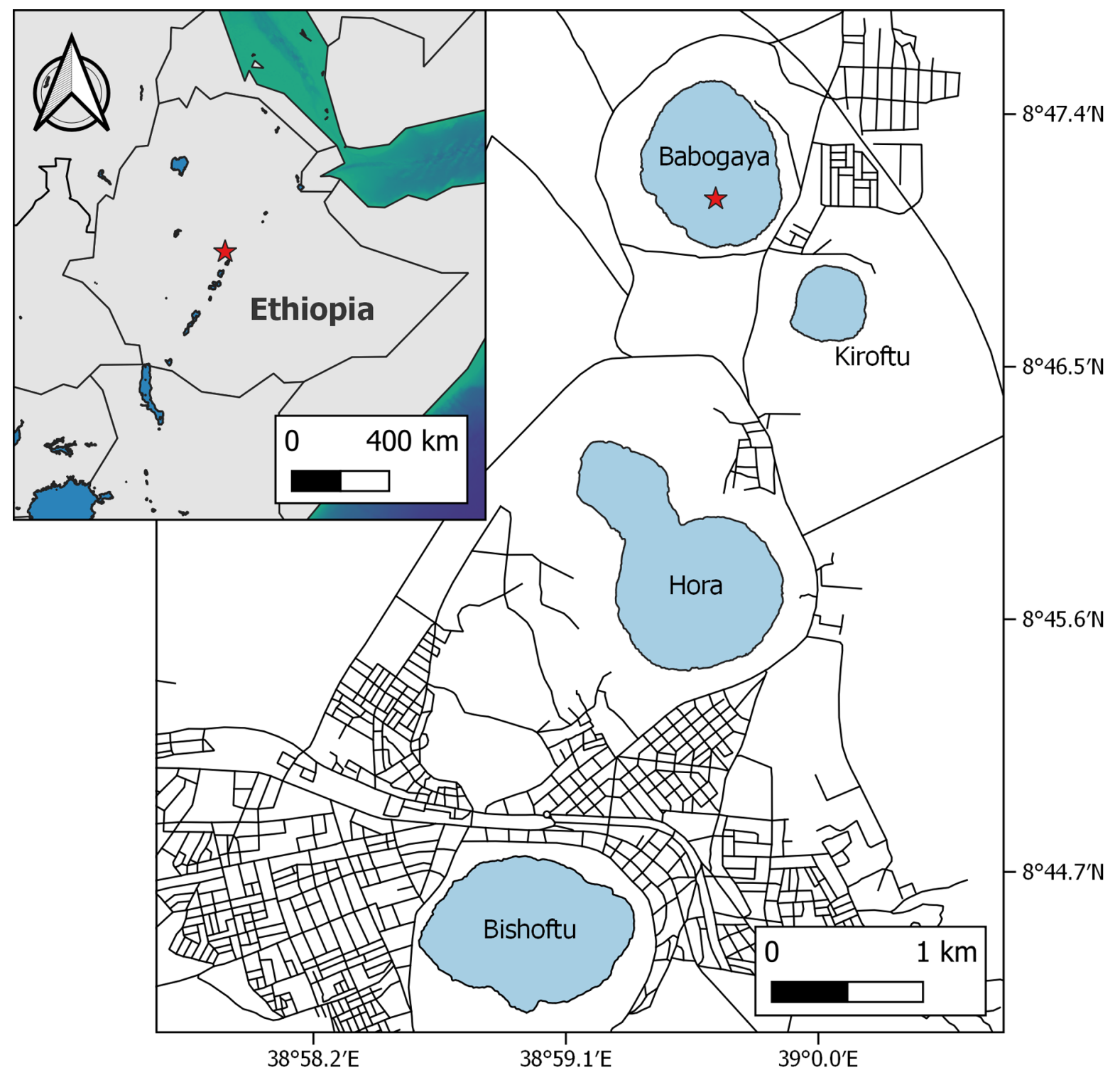

Fig. 1. Location of the Bishoftu crater lakes within Ethiopia (red point in inset map) and the Bishoftu area (black lines indicate roads). 
of the Results and Discussion section, so that the name can be used throughout the remainder of the paper.

\section{Materials ANd Methods}

Study site. The samples studied came from a core taken at Lake Babogaya, Ethiopia (Fig. 1). Lake Babogaya (also known as Bishoftu Guda or Pawlo), is a $65 \mathrm{~m}$ deep maar lake at an altitude of $1860 \mathrm{~m}$ above sea level, one of several crater lakes in Bishoftu, $\sim 50 \mathrm{~km} \mathrm{SE}$ of Addis Ababa. The local climate is monsoonal with distinct, pronounced wet and dry seasons (VISTE et al. 2013). Characteristic of many crater lakes, Lake Babogaya has steep slopes with a very small catchment area and no inflowing rivers or streams. Multiple researchers have conducted comprehensive investigations into the limnology of these crater lakes (BAXTER et al. 1965; WoOD et al. 1976, 1984; WoOd \& TAlLing 1988; LAMB et al. 2002; LemMA 2009), and as a result the hydrochemistry and seasonal variations of the relatively fresh (ca. 750-900 $\mu \mathrm{s} . \mathrm{cm}^{-1}$ ), alkaline (8.7-9.2 pH) Lake Babogaya are well understood (Table 1). Lake Babogaya develops thermal stratification during March through to November, leading to the formation of indistinct thermoclines at 11-16 m depth late in the summer wet season. The waters of the lake mix from November to February, during the dry season, associated with the evaporative and night-time radiative cooling under conditions of low humidity and low cloud cover, which is balanced with solar inputs. This mixing likely promotes algal photosynthesis and increased aragonite precipitation by bringing $\mathrm{Ca}$ and other nutrients from the hypolimnion to the surface. Presumably, it is this seasonal change in aragonite precipitation that has led to the formation of dark-light laminae in Lake Babogaya, as observed at neighbouring Lake Hora (LAMB et al. 2002). These laminated sediments offer the ability to reconstruct past environmental change at a high resolution. They are currently the subject of ongoing research using diatoms and geochemical data to reconstruct past hydrological conditions (GRADY et al., in prep).
Sample preparation and microscopy. A ca. $16 \mathrm{~m}$ core (BALC-2011; with a basal ${ }^{14} \mathrm{C}$ date of 5470 cal BP; Table S1) was extracted in October 2011 with a UWITEC corer by a team led by Prof. Frank SchäвITZ of Universität zu Köln.

Small $1 \mathrm{~cm}^{3}$ sediment samples were taken from the Babogaya core where the problematic Nitzschia sp. was abundant ( $>50 \%$ of total counted valves) (Aberystwyth DGES palaeoecology sample codes: QDP 2000, QDP 2018, QDP 2056 and QDP 2075). Samples were prepared for mounting with $70 \%$ nitric acid and rinsed (by decanting) with deionized water until samples were $\mathrm{pH}$ neutral. Aliquots of both Lake Babogaya sub-samples and type material were transferred to $21 \mathrm{~mm}$ and $13 \mathrm{~mm}$ coverslips and air-dried for LM and SEM analyses, respectively. Dried samples for SEM were fixed to aluminium stubs and sputtered with platinum for $70-80 \mathrm{~s}$ at 5 nm. min $^{-1}$ (at $25 \mathrm{~mA}$ ) using an Emitech $\mathrm{K} 575 \mathrm{X}$ peltier coater.

LM observations and morphometric measurements were performed with a Zeiss Axio Imager M2 using a Plan-Apochromat $\times 100$ objective (nominal numerical aperture: 1.4 ) with bright field and differential interference contrast optics; photographs were taken using an Axiocam HRc digital camera. Where it was important to obtain maximum resolution, especially to check the visibility of valve pores in LM, the condenser was oiled. Measurements were taken for $N$. fenestralis using the public domain Fiji (ImageJ distribution package) software (SCHINDELIN et al. 2012; RUEDEN et al. 2017).

SEM work was undertaken using a LEO Supra 55 model at $5 \mathrm{kV}$ and $4-5 \mathrm{~mm}$ working distance. All samples from Lake Babogaya used in this study, both LM slides and SEM stubs, have been archived at the Royal Botanic Garden Edinburgh (RBGE, herbarium code E).

In order to check that $N$. fenestralis is distinct from species already published, type material (slide and unmounted material) of $N$. aequalis (slides 241/64 and 241/65 of sample A348 and slide 241/74 of sample A354), N. mediocris (slide 243/6 and sample A409), and N. obsoleta (slides 242/21 and 242/22 and sample A382) was borrowed from the HusteDT collection in the Alfred Wegener Institute, Bremerhaven.

Table 1. Hydrochemistry of the Debre Zeit area groundwater (Gr) and Lake Babogaya (BA).

\begin{tabular}{|c|c|c|c|c|c|c|c|c|c|c|c|}
\hline & & \multirow{2}{*}{$\begin{array}{l}\text { Conductivity } \\
\left(\mathrm{k} 20 \mu \mathrm{S} . \mathrm{cm}^{-1}\right)\end{array}$} & \multirow{2}{*}{ pH } & $\mathrm{HCO}_{3}^{-}$ & $\mathrm{Cl}^{-}$ & $\mathrm{SO}_{4}{ }^{2-}$ & $\mathrm{CO}_{3}{ }^{2-}$ & $\mathbf{K}^{+}$ & $\mathbf{N a}^{+}$ & $\mathrm{Ca}^{2+}$ & $\mathrm{Mg}^{2+}$ \\
\hline & & & & \multicolumn{8}{|c|}{$\left(\right.$ meq. $\left.1^{-1}\right)$} \\
\hline \multicolumn{2}{|r|}{$\mathrm{Gr}^{1}$} & 685 & 7.3 & 2.62 & 0.42 & - & - & - & 0.42 & 1.98 & 2.52 \\
\hline \multicolumn{2}{|r|}{$\mathrm{BA}^{1}$} & 776 & $8.7-9.2$ & 7.67 & 0.69 & - & - & - & 3.74 & 0.22 & 3.74 \\
\hline \multirow{6}{*}{$\mathrm{BA}^{2}$} & $0 \mathrm{~m}$ & $850( \pm 30)$ & - & 2.55 & 0.06 & 4.09 & 2.70 & 0.37 & 2.33 & 0.84 & 3.72 \\
\hline & $3 \mathrm{~m}$ & $841( \pm 28)$ & - & 4.20 & 0.11 & 3.51 & 3.00 & 0.72 & 4.97 & 0.80 & 3.92 \\
\hline & $6 \mathrm{~m}$ & $829( \pm 15)$ & - & 4.30 & 0.11 & 2.28 & 2.90 & 0.76 & 4.97 & 0.60 & 4.64 \\
\hline & $16 \mathrm{~m}$ & $859( \pm 14)$ & - & 4.60 & 0.11 & 2.68 & 2.60 & 0.62 & 4.58 & 0.68 & 4.36 \\
\hline & $30 \mathrm{~m}$ & $959( \pm 12)$ & - & 5.99 & 0.10 & 2.79 & 1.90 & 0.45 & 2.84 & 0.68 & 4.72 \\
\hline & $50 \mathrm{~m}$ & - & - & 5.49 & 0.10 & 2.08 & 1.70 & 0.42 & 2.52 & 0.60 & 4.52 \\
\hline
\end{tabular}

${ }^{1}$ Surface water in 1998, from LamB et al. (2002).

${ }^{2}$ Surface waters to $50 \mathrm{~m}$ depth in 2001, from Lemma (2009). 


\section{Results AND Discussion}

\section{Nitzschia fenestralis D. Grady, D.G. Mann et Trobajo sp. nov., (Figs 2-20, 23, 26, 30, 34, LM; 36-39, 41, 42, 45-49, SEM)}

LM description: Valves are narrow, 1.9-3.3 $\mu \mathrm{m}$ (average $=2.46 \pm 0.29 \mu \mathrm{m})$, linear-lanceolate with parallel sides centrally in longer valves (Figs 2-4) and acutely rounded, or sometimes slightly subrostrate poles. The length of the valve is $20-70 \mu \mathrm{m}$, but with the mean valve length being $40.65 \pm 9.38 \mu \mathrm{m}(\mathrm{n}=210)$. Fibulae short and spaced regularly, with $12-14$ in $10 \mu \mathrm{m}$; the central pair of fibulae are no more widely spaced than the others $(n=210)$. Striae (and even the areolae too: Figs 26, 30) are visible under LM with good optics, but counted in this study under SEM, numbering $32-35$ in $10 \mu \mathrm{m}$ (n $=60$ ). All morphology metrics are available in Table 2 .
SEM observations: The fibulae are squarish and connected on each side of the raphe by a narrow longitudinal ridge $(n=60$; Figs $46, \mathrm{~S} 5, \mathrm{~S} 6)$. The areolae adjacent to the raphe (i.e. on the raphe canal) are divided in two, parallel to the raphe $(n=60$; Figs $45,47, S 1-4)$. The raphe is continuous from pole to pole (Figs 41, 42, 45, S2, S3), agreeing with the absence of a wider central fibula spacing $(\mathrm{n}=32)$, and sits on a shallow keel at the junction between the mantle and the valve face (Figs 42, 45); it curves slightly at the poles (Fig. 47). The striae are uniseriate, composed of small round areolae (Figs $42,45,46,49$, S2-6). In all of the 60 samples examined by SEM, the areolae lacked hymenes (e.g. Figs 45-47). We interpret this as a consequence of dissolution and that hymenes are present in intact organisms and frustules (cf. N. obsoleta: Fig. 50). The striae continue on to the valve mantle but are interrupted by a small ridge on the

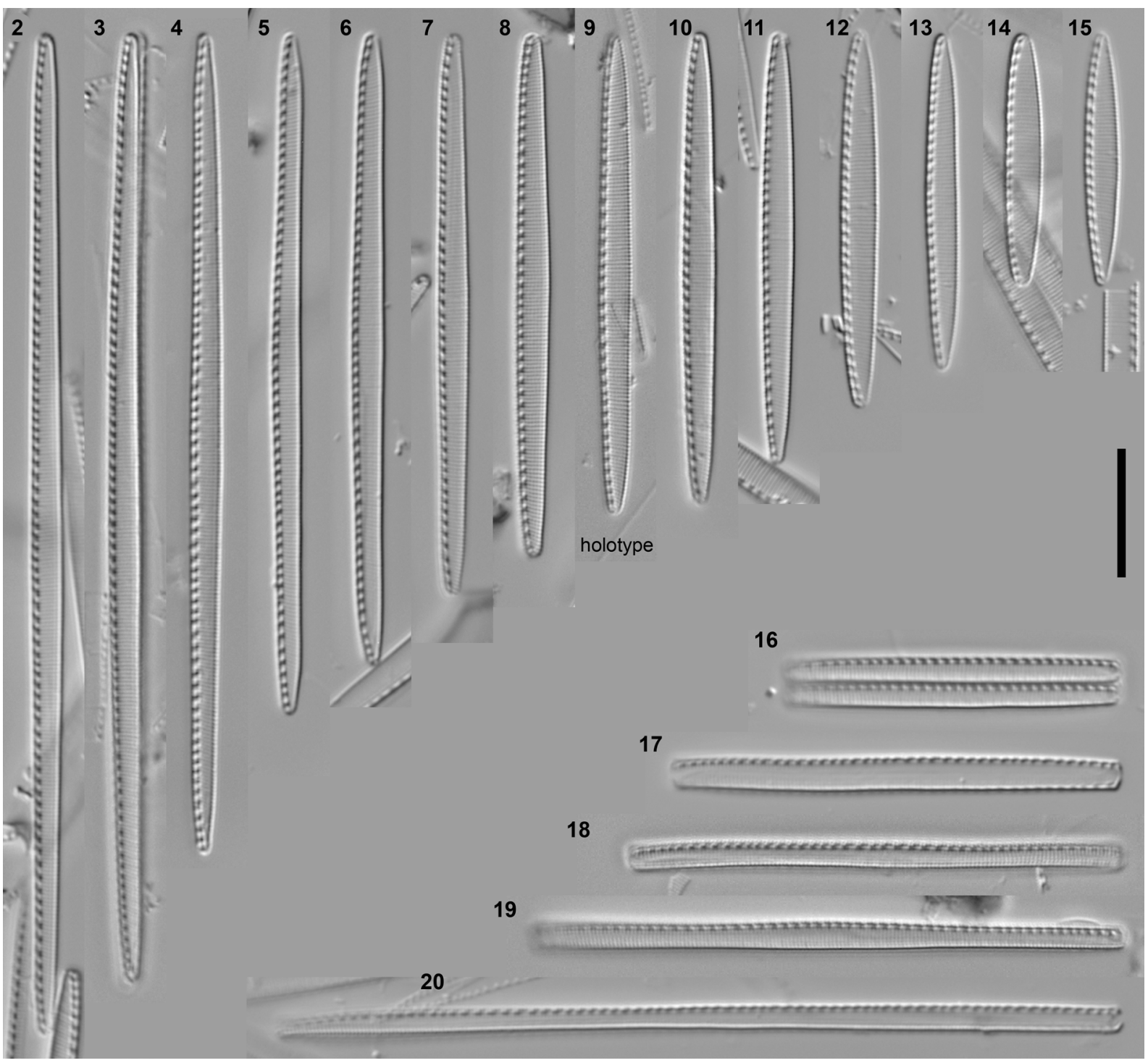

Figs 2-20. Nitzschia fenestralis sp. nov., cleaned valves and frustules from Lake Babogaya, LM, DIC optics: (2-15) Series of valves, interpreted as representing size reduction during the life cycle, in valve view (the holotype of $N$. fenestralis is shown in Fig. 9). Note the even spacing of all the fibulae. (16) A recently divided vegetative cell in girdle view, showing nitzschioid symmetry of both daughter frustules. (17-20) Frustules of various lengths in girdle view; all are nitzschioid. Scale bar $10 \mu \mathrm{m}$. 


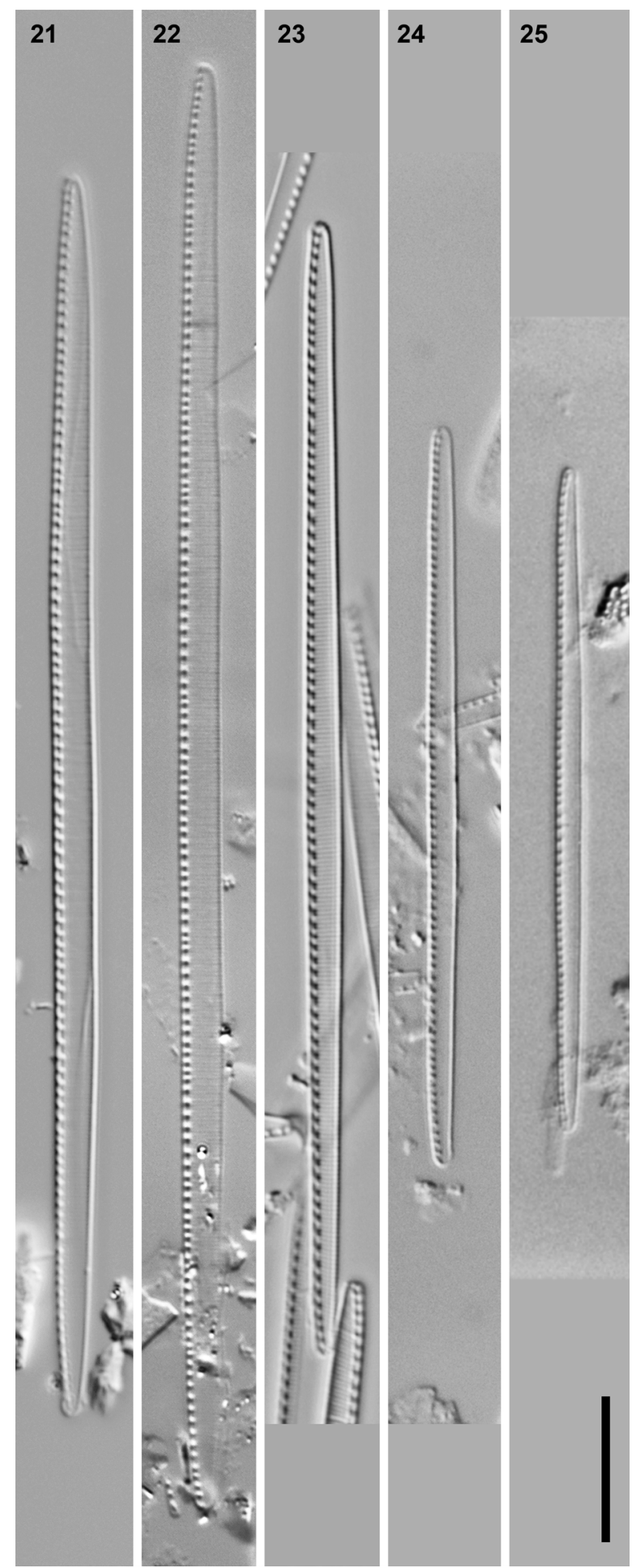

Figs 21-25. Comparison of valves of similar linear Nitzschia species lacking a central nodule from tropical African lakes, LM, DIC optics: (21) Paralectotype of $N$. aequalis (ringed specimen on Hustedt collection slide 241/65 from Lake Edward: this specimen was also photographed by SimONSEN 1987, pl. 530, figs 3, 4). (22) Another specimen of $N$. aequalis (on Hustedt collection slide 241/74, again from Lake Edward). (23) Long specimen of $N$. fenestralis (also shown in Fig. 1). (24, 25) Nitzschia mediocris (Hustedt collection, slide 243/6, Nyamirundi, Lake Kivu). Scale bar $10 \mu \mathrm{m}$.

junction between the mantle and valve face (Figs 49, S4). The striae are parallel for most of the valve but become strongly radiate at the poles (Figs 36-39, $\mathrm{n}=45$ ), this feature can also be seen in LM with good optics. There is often a fault in the striation near the centre of the valve (Fig. 36). A small helictoglossa is present at the ends of the raphe internally on the internal side of the valve (Fig. S5; $n=35$ ). Many loose or attached girdle bands were observed during SEM, each possessing two rows of small areolae (Figs 48, 49, S7; $\mathrm{n}=14$ ). Unlike in most diatoms, the open ends of the first two bands were positioned approximately halfway along the side of the frustule, rather than at the poles (Fig. 49).

Holotype: Slide E6092/1 Herbarium, Royal Botanic Garden Edinburgh, Scotland, from $596 \mathrm{~cm}$ depth $(\sim 3,000$ cal BP) in the BA-LC-2011 core. The holotype specimen is shown in Fig. 9 and is located at England Finder J40, between centre and 2. See Fig. S9 for a context image. Isotype: Slide Zu11/26 Hustedt Collection, Bremerhaven, Germany.

Type locality: Lake Babogaya $\left(08^{\circ} 47^{\prime} 08^{\prime \prime} \mathrm{N}, 38^{\circ} 59^{\prime} 38.5^{\prime \prime} \mathrm{E}\right)$, Ethiopia: sediment core sample (present throughout from $\sim 5400$ cal BP at the base of core to the core top at $\sim 600$ cal BP). The species is also present at $14.7 \%$ relative abundance (slide number QDP 885: Aberystwyth University DGES collection) in the top $1 \mathrm{~cm}$ of a surface core taken in 1998 (GRADY, unpublished data) suggesting the species is likely extant; however, further work is required to confirm this.

Distribution: only reported from Lake Babogaya to the authors' knowledge (but see our comments below on a similar diatom reported by GASSE).

Etymology: the specific epithet given to this taxon refers to the resemblance of the divided areolae to small sash windows, with the pores lacking plates looking like multiple rows of the windows when open.

\section{Morphology of $N$. fenestralis and similar species}

The samples from the Lake Babogaya core were very rich in $N$. fenestralis and it seems there is a continuous series of valves illustrating what we think are the changes that occur during the life cycle (Figs 2-20). As has been found in many Nitzschia species (GEISSLER 1970a, b; Trobajo et al. 2011, 2013; Rovira et al. 2015) the length of $N$. fenestralis varies considerably due to the life cycle whereas the width alters much less (both relatively and absolutely; see Figs 2-15). Consequently, the shape of the cells is rather different at the two ends of the size reduction series and if either end was seen in isolation it would be easy to think they belong to different species. An unusual feature of $N$. fenestralis is that the striae are obviously oblique to the apical axis towards the poles (Figs 36-39; also detectable in Figs 2-15). This is something that we hadn't noticed before in any other long, linear Nitzschia species. Interestingly, it is also present in $N$. obsoleta, though less strongly developed (Figs 40, 43), and perhaps also in the recently described N. fabiennejansseniana (CoCQUYT \& RYKEN 2017; figs 32,33 ). Furthermore, in terms of morphometrics (length, width, stria and fibula density: Table 2, Fig. 51), as well as in valve outline, $N$. fenestralis, $N$. obsoleta and $N$. 


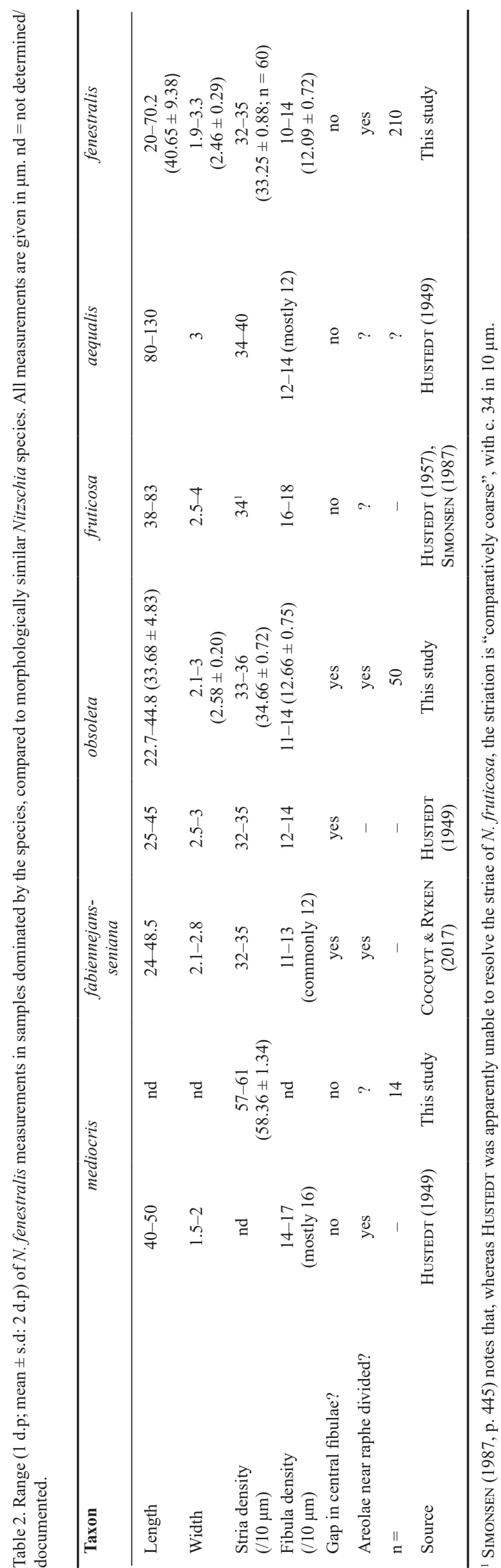

fabiennejansseniana are similar (Figs 34, 35; CocQuYT \& RYKEN 2017, figs 2-29). However, they are clearly separated by the presence ( $N$. obsoleta and $N$. fabiennejansseniana) or absence ( $N$. fenestralis) of central raphe endings (Figs 26, 27, 41-44, and see COCQUYT \& RYKen 2017, figs 30,31). The taxonomic utility of this character was already recognized in the publication where N. obsoleta was first described (HusteDT 1949, p. 134) and often since (e.g. Krammer \& LANGe-Bertalot 1988; Trobajo et al. 2004; Trobajo et al. 2013).

Interestingly, under SEM, these three taxa $(N$. fenestralis, $N$. obsoleta and $N$. fabiennejansseniana) also share the distinctive feature of having areolae in the raphe canal divided in two (Figs 42, 45 and 47 for fenestralis, Figs 44 and 50 for obsoleta and CocQuYT \& RYKEN 2017, figs 30-33 for fabiennejansseniana). We also observed this feature for $N$. mediocris (not illustrated); however, this taxon, despite the absence of central raphe endings, is separated from $N$. fenestralis by its narrower valves and much higher stria density (Table 2, Figs 24, 25, 33). Although $N$. fenestralis can be separated from $N$. obsoleta and $N$. fabiennejansseniana by the absence of central raphe endings, it is less clear whether $N$. obsoleta and N. fabiennejansseniana can be separated from each other. There is no obvious difference between them in valve structure and, as Table 2 shows, these two species cannot be separated by length, width, and fibula and stria density. Comparisons between these two species were not included in COCQUYT \& RYKEN's (2017) paper describing $N$. fabiennejansseniana but it seems very likely to us that it is a later synonym of $N$. obsoleta. However, this issue was not the focus of our work and a final decision should await a more complete examination of both species.

When considering general valve outline, $N$. aequalis and $N$. fruticosa are also very similar to $N$. fenestralis, and also have a continuous raphe, however $N$. aequalis (Figs 21,22) has much longer valves than $N$. fenestralis. Despite measuring 210 valves of $N$. fenestralis and scanning slides for longer specimens, the longest valves we found were ca $70 \mu \mathrm{m}$ whereas the range recorded for $N$. aequalis by Hustedt (1949) was $80-130 \mu \mathrm{m}$ (Table 2 ); the two valves that we measured of $N$. aequalis were also more finely striated ( 37 or 38 striae in $10 \mu \mathrm{m}$ ) than $N$. fenestralis, although HustedT gave a wider range (Table 2). Nitzschia fruticosa has slightly wider valves and a higher fibula density than $N$. fenestralis (Table 2). The figures of $N$. fruticosa given by Simonsen (1987, pl. 661, figs 7-11) and Krammer \& LANGE-BerTalot (1988, pl. 60, figs 8-12) show a diatom with more attenuated, narrower ends than $N$. fenestralis and striae that are parallel throughout.

Other somewhat similar taxa are: In terms of valve outline, N. pseudoaequalis Cocquyt et Ryken, N. intermissa Hustedt, $N$. bacata Hustedt (especially $N$. bacata f. linearis Hustedt) are also similar to $N$. fenestralis. However, alongside morphometrics such as different 

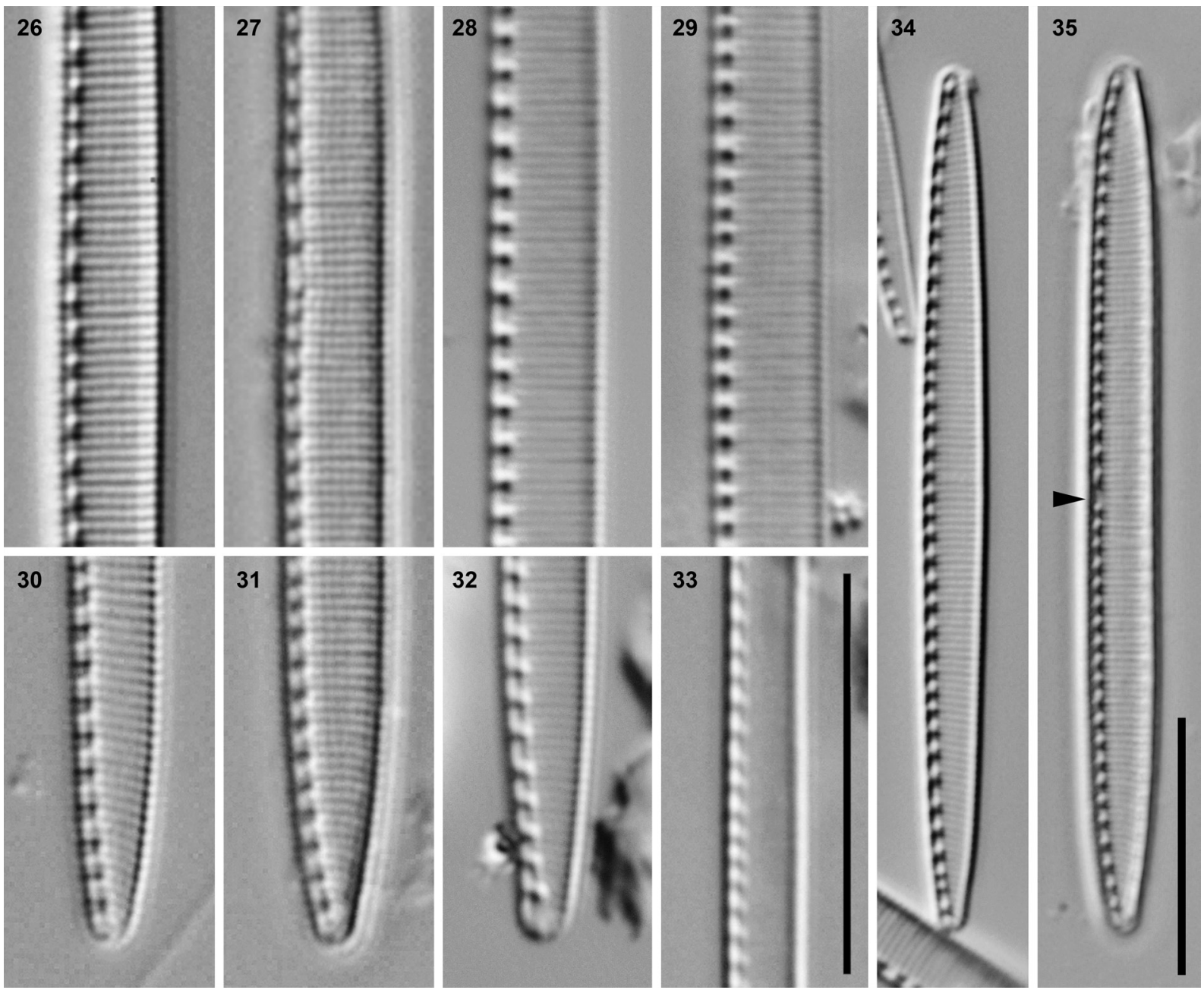

Figs 26-35. Comparison of Nitzschia fenestralis, $N$. obsoleta, N. aequalis and N. mediocris, LM, DIC optics: (26-29) Valve centres of $N$. fenestralis (Fig. 26), N. obsoleta (Fig. 27, from Hustedt collection slide 242/21, from off algae in Lake Edward), and N. aequalis (paralectotype shown in Fig. 28, a second valve in Fig. 29). Note that the striae are less dense in N. fenestralis and N. obsoleta (33 and 34.5 in $10 \mu \mathrm{m}$ respectively) than in $N$. aequalis (38 and 37.5 in $10 \mu \mathrm{m}$ ); in addition, the areolae are resolved in $N$. fenestralis and $N$. obsoleta, but not N. aequalis. (30-32) Valve ends of $N$. fenestralis, $N$. obsoleta and $N$. aequalis (paralectotype), respectively. (33) Centre of N. mediocris. (34) Nitzschia fenestralis: note the even spacing of all fibulae and the radiate orientation of the striae towards the poles. (35) Nitzschia obsoleta: the two central fibulae are more widely spaced and a central nodule can be detected between them (arrowhead). Scale bars $10 \mu \mathrm{m}$ (in Fig. 33 for Figs 26-33, in Fig. 35 for Figs 34, 35).

stria density or valve width, critically all these taxa possess central raphe endings. Conversely, numerous taxa, such as $N$. abonuensis Foged, N. etoshensis Cholnoky, $N$. asterionelloides O. Müller, share the lack of central raphe endings with $N$. fenestralis and are also similar in terms of valve outline (FoGED 1966; СHOLNOKY 1966). However, the stria and fibula density of these taxa are finer (N. etoshensis and N. asterionelloides) or coarser (N. abonuensis) than those of $N$. fenestralis. Additionally, the widths of $N$. etoshensis $(4-5.5 \mu \mathrm{m})$ and $N$. asterionelloides $(1.6-1.8 \mu \mathrm{m})$ separate these species from $N$. fenestralis $(1.9-3.3 \mu \mathrm{m})$.

In her seminal work on the diatoms of East Africa, GASSE (1986, pl. 35, fig. 13) illustrated a specimen with somewhat similar morphology to $N$. fenestralis which she placed in the broad $N$. palea complex as $N$. aff. palea, despite the taxa of this complex normally having rostrate apices (e.g. Krammer \& Lange-Bertalot 1988; Morales
\& Hamilton 2002; TaYlor et al. 2007, Trobajo et al. 2009). Further work is needed to confirm whether $N$. aff. palea of GASSE is indeed $N$. fenestralis or not.

\section{Noteworthy morphological features of $N$. fenestralis} As noted above, the radiate orientation of the striae towards the poles in $N$. fenestralis is apparently unusual in Nitzschia. However, it is possible that it has been overlooked elsewhere, especially in long delicate species. Whole valves are often illustrated only as LMs, while SEM images show only details of the ultrastructure (e.g. raphe structure, areolae, girdle bands). Thus, in the LMs of whole valves of $N$. fabiennejansseniana given by COCQUYT \& RYKen (2017) the striae are mostly invisible and the poles of this species are shown for only one valve in SEM (ibid., figs 32, 33); this particular valve had radiate polar striae like $N$ fenestralis but it is unclear whether this is characteristic of $N$. fabiennejansseniana 


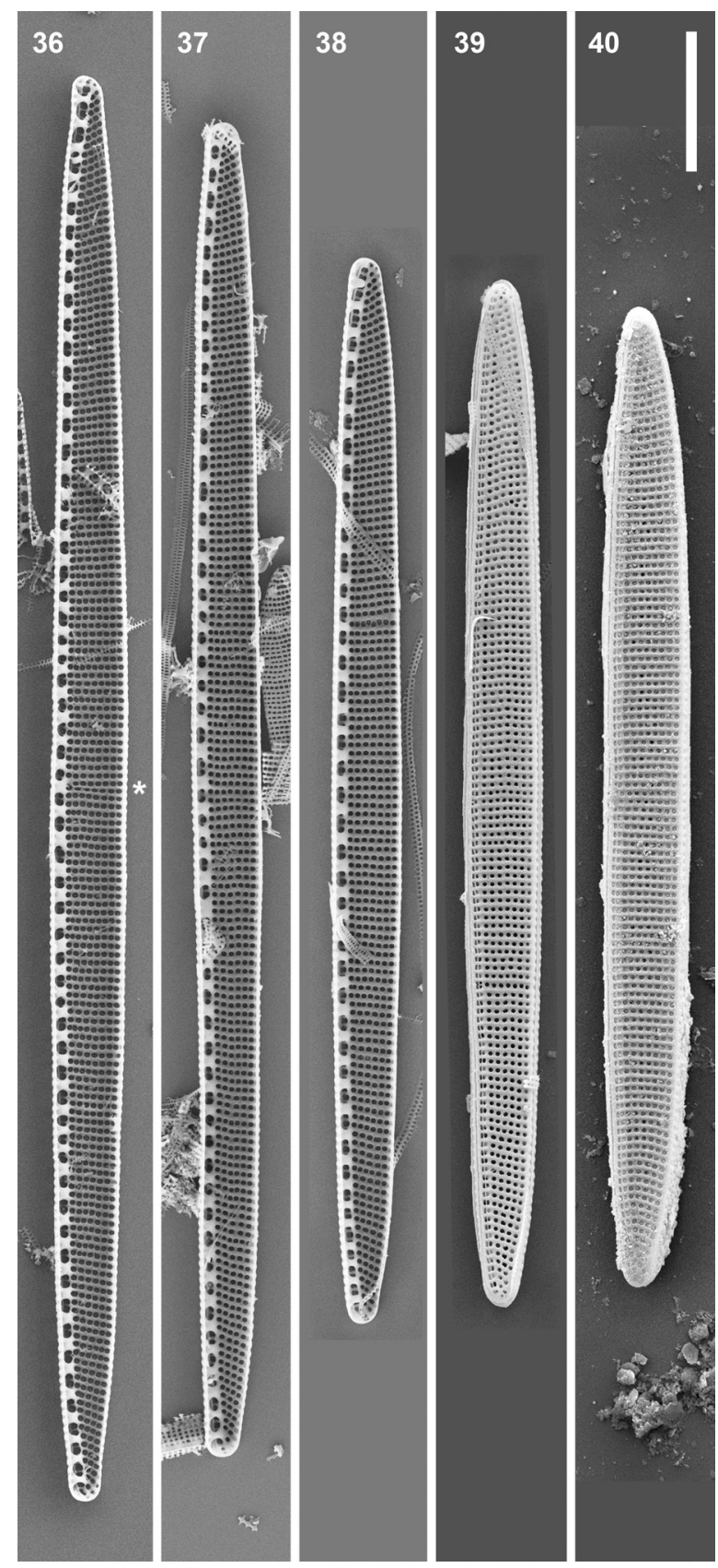

Figs 36-40. Nitzschia fenestralis and $N$. obsoleta, whole valves, SEM, all untitled and presented with the raphe system to the left. Here and in Figs 41-50 and S1-S8, N. fenestralis is illustrated from sample QDP 2000 and N. obsoleta from Hustedt sample A382 (which is the sample from which LM slide 242/21 in the Hustedt collection was prepared). (36-38) Nitzschia fenestralis, internal views, showing more or less evenly spaced fibulae and striae that become strongly radiate towards the apices. (39) Nitzschia fenestralis, external view. (40) Nitzschia obsoleta, external view. Scale bar $10 \mu \mathrm{m}$.

or not and stria orientation is not mentioned in COCQUYT \& RYKEN's (2017) description of the species.

The structure of the raphe canal is proving valuable for characterizing species of Nitzschia and related genera (e.g. Trobajo et al. 2012, 2013). Several variants are known. In one, the raphe canal walls lack areolae altogether (e.g. in Pseudo-nitzschia and Fragilariopsis: e.g. MAnN 1978). Elsewhere, there may be a single longitudinal row of areolae, one opposite each stria of the valve face (e.g. Rovira et al. 2015), several longitudinal rows (e.g. N. sigmoidea: MANN 1986, figs 3, 4), or a complex structure, in which each valve stria is represented within the raphe canal by a cluster of three or more small areolae (e.g. $N$. fonticola, $N$. soratensis: Trobajo et al. 2006, 2013). The paired areolae in the raphe canal of $N$. fenestralis represent a further type, present also in $N$. obsoleta and $N$. fabiennejansseniana (if this is separate from $N$. obsoleta) and may perhaps be characteristic of a subgroup of Nitzschia that has not previously been recognized.

A further interesting feature, which we have never seen reported before in any other diatom, is the presence of short bands in both $N$. fenestralis and $N$. obsoleta, each band reaching from the pole to approximately half way along the girdle on either side. The material of $N$. fenestralis was too fragmented for us to be able to determine how many such bands there are in a theca: there are at least two. In N. obsoleta there are four, arranged alternately; only the much narrower fifth band is of normal length, extending around the whole circumference of the cell and open at one pole (Figs 50, S8).

\section{Ecology and associated diatoms}

All samples of the core studied contained Nitzschia species (Fig. 52) and in most of them they represented $>30 \%$ of the diatom community; indeed, in a few samples Nitzschia made up nearly $100 \%$ of the total community (Fig. 52). As discussed above, Nitzschia-dominated waterbodies are not as unusual in tropical Africa as elsewhere, with the early classification of African lakes (HUSTEDT 1949; TALLing \& TALLING 1965; RichaRdSON 1968) containing a whole class and sub-class of lakes partially characterised by high abundances of Nitzschia taxa (class III and subclass IIb) and also by lake alkalinity.

Nitzschia fenestralis was observed throughout the core record but was most abundant ( $>35 \%$ relative abundance) in samples between 300 and $800 \mathrm{~cm}$ sediment depth (Figs 52, 53) in association with the freshwater Nitzschia paleacea (Grunow) Van Heurck, Nitzschia lancettula O. Müller and Nitzschia gracilis Hantzsch sensu Gasse (1986). Among other species present with Nitzschia fenestralis in certain sections were predominantly freshwater taxa such as Nitzschia palea (Kützing) Smith, N. "group latens" (sensu GASSE 1986), Aulacoseira granulata (Ehrenberg) Simonsen and Fragilaria-type taxa such as Pseudostaurosira brevistriata (Grunow) Williams et Round and Ulnaria ulna (Kützing) Compère.

Although it is important to note the role of numerous other environmental factors (such as water salinity and turbidity to name a couple), the distribution of diatom taxa in Africa have been linked with hydrochemistry in terms of alkalinity and $\mathrm{pH}$, especially Nitzschia spp. (e.g. class IIb lakes in RicHARDSON (1968)). For example, based on their eastern African diatom dataset (initial dataset consisting of 156 samples containing 579 taxa 

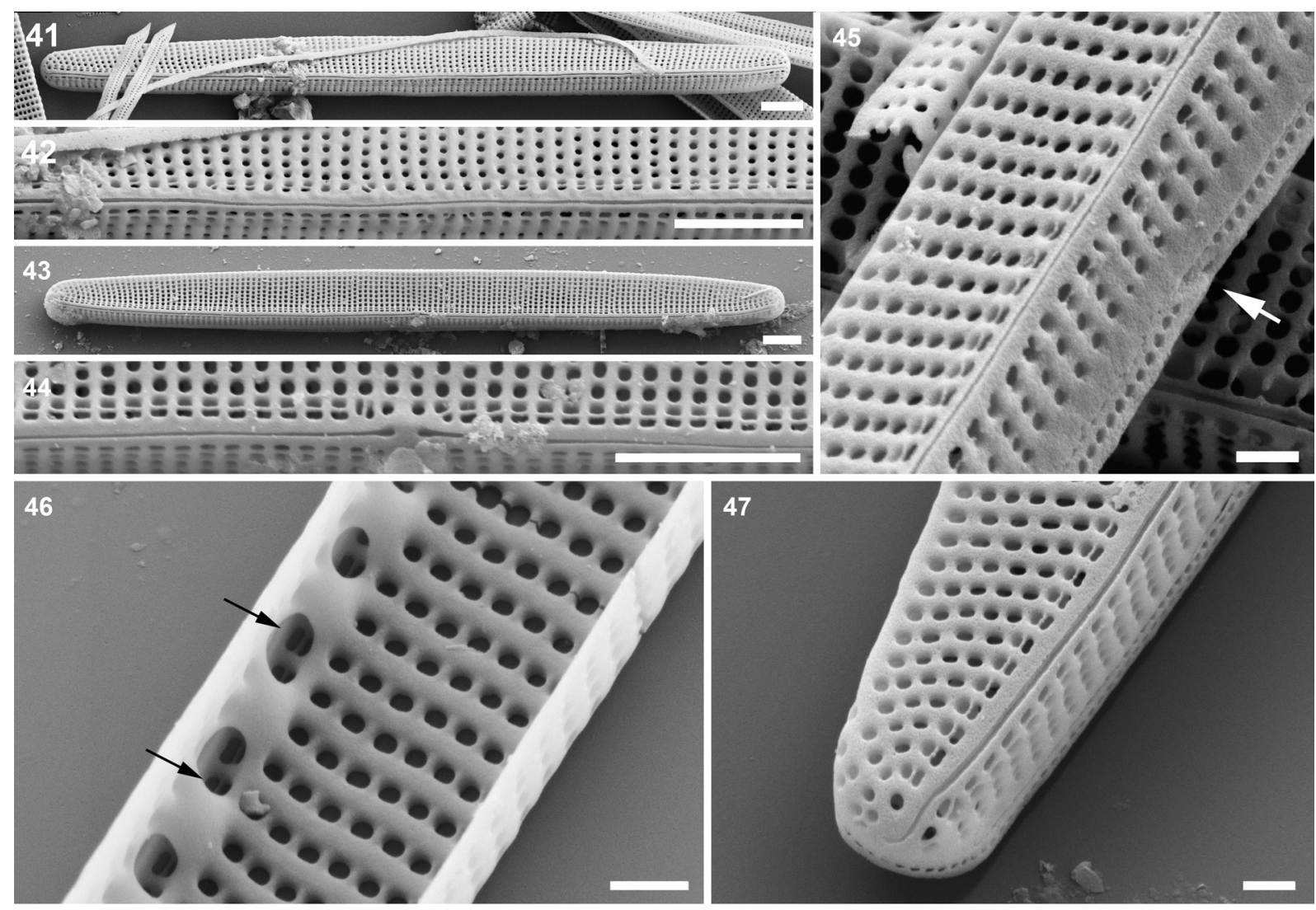

48

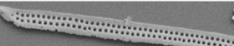

\section{\&}

-

\section{(}
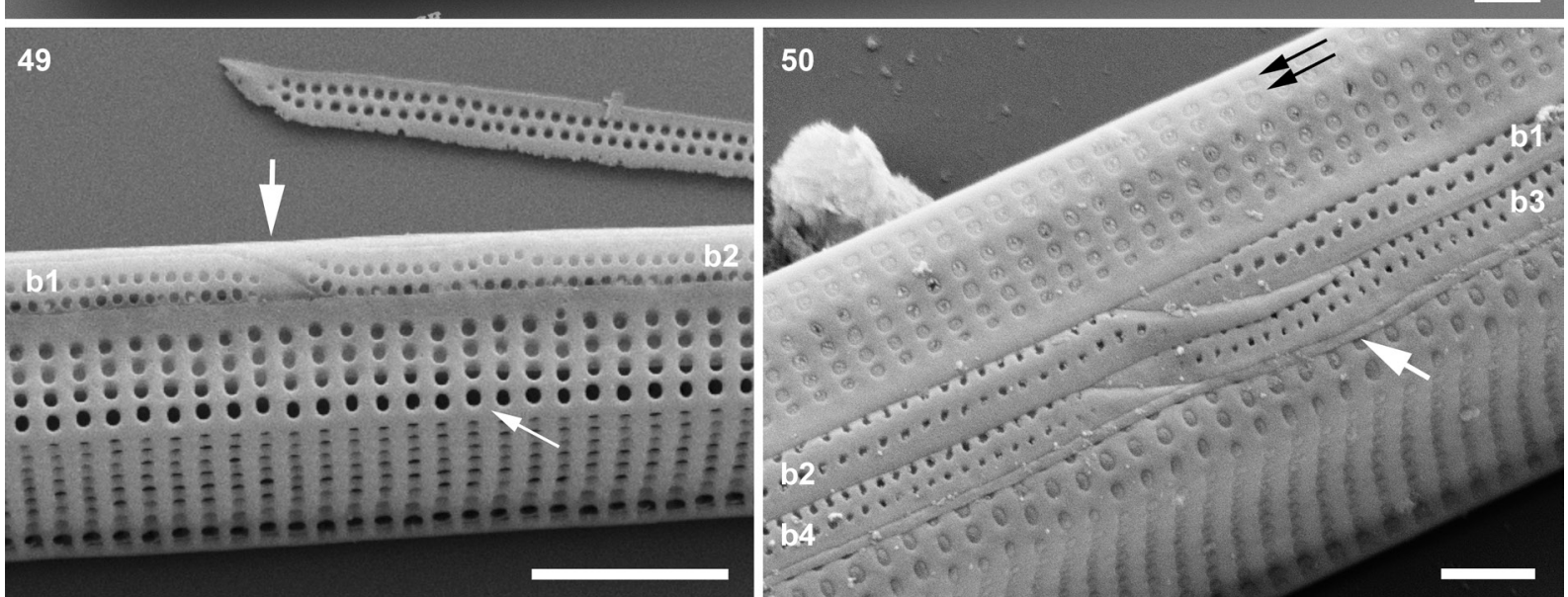

Figs 41-50. Nitzschia fenestralis and N. obsoleta, details of external frustule ultrastructure (except Fig. 46), SEM; all tilted 25 : $(41,42)$ Whole valve context and centre of $N$. fenestralis: the raphe is continuous. $(43,44)$ Whole valve context and centre of $N$. obsoleta: central raphe endings are present; this specimen is eroded and has lost its hymenes (contrast Fig. 50). (45) Nitzschia fenestralis, centre, showing continuous raphe , deep valve mantle, the double row of poroids on each side of the raphe within the raphe canal (see also Fig. 47), and a split in the girdle bands at the centre (arrow). (46) Nitzschia fenestralis, internal view. The bases of the fibulae are linked by a longitudinal ridge, creating elliptical portulae linking the raphe canal with the valve interior. The double poroids in the raphe canal are visible (e.g. arrows). (47) Nitzschia fenestralis, valve pole, showing slightly bent terminal fissure and the double row of narrower areolae in the raphe canal. $(48,49)$ Whole valve context and centre of a disassembled, incomplete theca of $N$. fenestralis, showing the open ends (at large arrow) of band 1 (b1) and band 2 (b2), which both bear two rows of closely spaced round poroids; the other end of band 2 is also visible, lying free on the stub (above arrow). Note also the deep valve mantle, where each stria is represented by four areolae, and the slight interruption of the striae at the valve face-mantle junction (narrow arrow). (50) Nitzschia obsoleta, centre of frustule in girdle view. Note the double row of areolae (black arrows) in the raphe canal, deep valve mantle with four areolae in each stria (cf. Fig. 49), open ends of bands 1-4 (b1-b4), each with two rows of small round areolae, and the narrower, imperforate band 5 (white arrow), which is not interrupted at the centre. Note also that each valve areola is occluded by a hymen close to its external aperture. Scale bars $2 \mu \mathrm{m}(41-44,48,49)$ or $500 \mathrm{~nm}(45-47,50)$. 

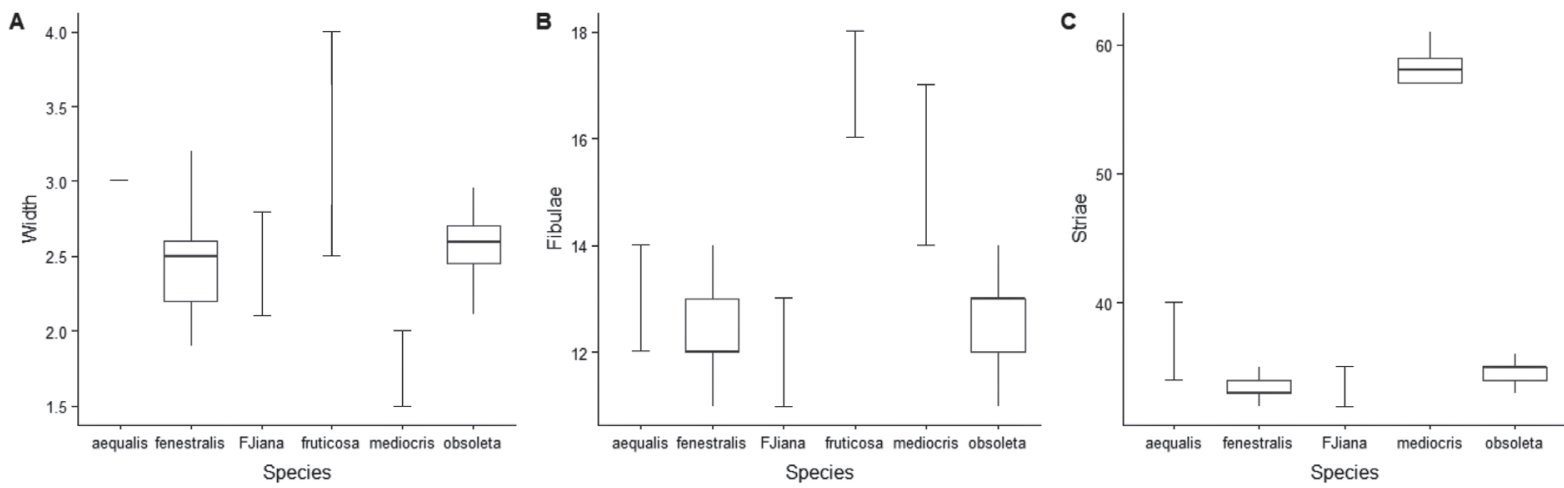

Fig. 51. Width (A), striae (B) and fibulae (C) density of Nitzschia fenestralis and similar Nitzschia taxa, (FJiana) fabiennejansseniana. Box plots are included for metrics measured in this study, with whiskers only for morphometrics published elsewhere cited in text.

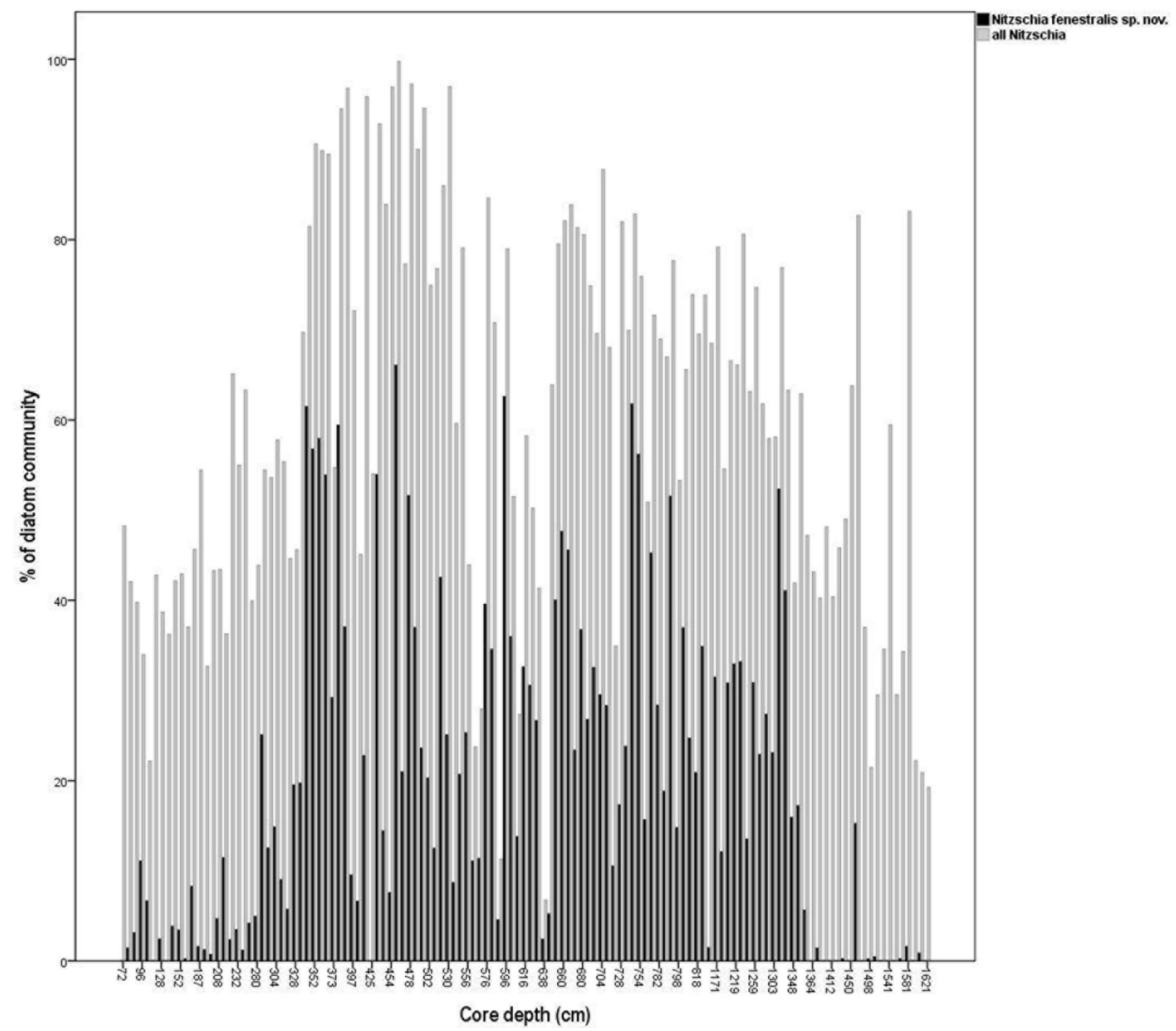

Fig. 52. Abundance of Nitzschia fenestralis, and Nitzschia in general, in samples taken through the Lake Babogaya core.

across 98 sites), GASSE \& TEKAIA (1983) suggest that Pseudostaurosira brevistriata and Nitzschia lancettula, taxa common alongside $N$. fenestralis in the Babogaya core, are indicator taxa for a lake $\mathrm{pH}$ of around 8 to 8.6, with the combined African dataset (GASSE et al. 1995;
282 samples containing 665 taxa across 164 sites) suggesting $\mathrm{pH}$ optima of $7.82 \pm 1.02$ and $8.51 \pm 0.76 \mathrm{pH}$ for $P$. brevistriata and $N$. lancettula, respectively. The same combined African dataset gives an optimum of $\sim 7.6 \mathrm{pH}$ for both $N$. palea and N. paleacea, species 


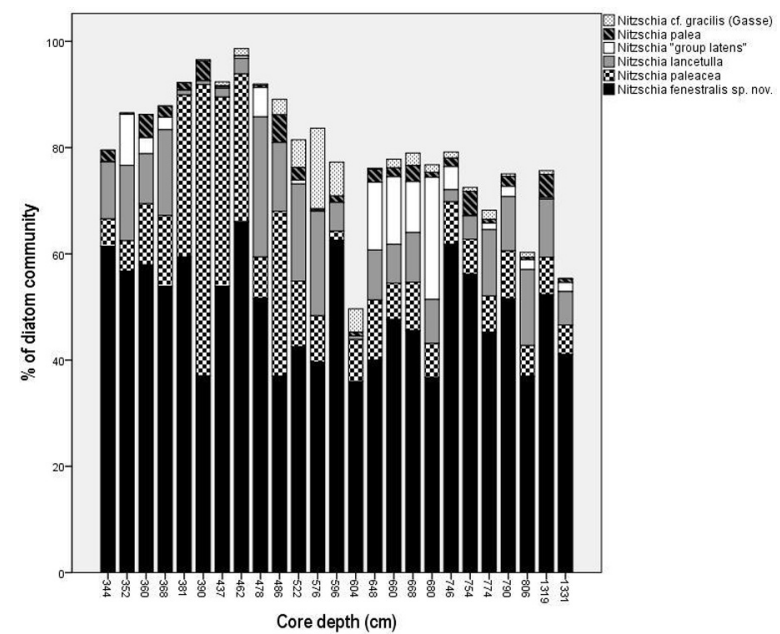

Fig. 53. Abundance of Nitzschia fenestralis and other Nitzschia taxa when $N$. fenestralis abundance was $>35 \%$ in a sample.

that are also common with $N$. fenestralis. However, the composition of a plankton community (including the abundance of Nitzschia species such as N. paleacea) is also influenced by nutrient availability (especially N, Si and P; e.g. KILHam et al. 1986; VAN Dam et al. 1994; BAIER et al. 2004). Furthermore, factors such as lake water temperature and mixing are also important in controlling Nitzschia abundance (KILHAM et al. 1986; WOODBRIDGE \& RoBERTs 2010), illustrating the complex, multifactorial influences on plankton composition and that further work is required to fully understand the ecology of $N$. fenestralis.

The genus Nitzschia is widely distributed and abundant in several types of ecosystems but is taxonomically difficult. Nitzschia species often have very few distinguishing morphological characters that can be seen in LM, making them notoriously difficult to accurately identify. Even in SEM, their recognition can be difficult; not surprisingly, therefore, Nitzschia studied under LM are often identified at genus level only (or with "aff." to similar species) in (palaeo)ecological and taxonomic studies (e.g. GASSE 1986; LEGESSE et al. 2002; MoRALES \& HAMiLTON 2002; Krstić et al. 2012). However, the ability to recognize and differentiate a species is a prerequisite to fully understand and utilise the ecology of that species. The present study, in which a hitherto unknown diatom has been found to dominate the diatom assemblage of a lake for a large part of its history, illustrates what would be missed by not recognizing it as different from other species such as $N$. obsoleta, $N$. aequalis, etc. Only now that we can discriminate $N$. fenestralis from morphologically similar taxa is it possible to study its ecology and distribution, and therefore its potential use for investigating environmental changes (past and present) in this crater lake and perhaps elsewhere.

\section{ACKNOWLEDGEMENTS}

We are thankful to Professor Schäbitz of Universität zu Köln for use of the BA-LC-2011 core and Dr Bank Beszteri and Dr Andrea
Burfeid for very kindly arranging loans of Nitzschia types from the Hustedt collection at the Alfred Wegener Institut, Bremerhaven, Holly Wynne, Patrick Robson, Alan Cookson and Frieda Christie are gratefully acknowledged for their assistance and time in preparing samples and operating the equipment required for this research. Dr. Sarah Davies and Professor Henry Lamb are thanked for their time in supervising the $\mathrm{PhD}$ of $\mathrm{D}$. Grady and for their helpful comments on this manuscript. We would like to thank the anonymous reviewer whose helpful comments improved the manuscript and we also express our gratitude to Dr. Carlos Wetzel for sharing with us some of his excellent, as yet unpublished observations of Hustedt's Nitzschia types. We appreciate the support given by the Masonic Charitable Foundation and Aberystwyth University in funding the studentship of D. Grady, including research time at the RBGE. The authors also acknowledge support from the CERCA Programme/Generalitat de Catalunya. The Royal Botanic Garden Edinburgh is supported by the Scottish Government's Rural and Environment Science and Analytical Services Division.

\section{REFERENCES}

Baxter, R.; Prosser, M.; TAlling, J. \& Wood, R. (1965): Stratification in tropical African lakes at moderate altitude (1500 to $2000 \mathrm{~m}$ ). - Limnol. Oceanogr. 10: 511-520.

Снolnoky, B. (1966): Diatomeen assoziationen aus einigen Quellen in Südwest-Afrika und Bechuanaland. -Nova Hedwigia, Beih. 21: 163-244.

Cocquyt, C. \& Ryken, E. (2017): Two new needle-shaped Nitzschia taxa from a deep East African crater lake. - Diatom Res. 32: 465-475. doi: 10.1080/0269249X.2017.1401009.

Cocquyt, C. \& Vyverman, W. (2005): Phytoplankton in Lake Tanganyika: a comparison of community composition and biomass off Kigoma with previous studies 27 years ago. - J. Great Lakes Res. 31: 535-546. doi: 10.1016/ S0380-1330(05)70282-3.

Cocquyt, C.; De HaAn, M.; Jahn, R. \& Hinz, F. (2012): Nitzschia epiphytica, N. epiphyticoides and N. pseudepiphytica (Bacillariophyta), three small diatoms from East and Central Africa. - Phycologia 51: 126-134. doi: $10.2216 / 10-61.1$.

Foged, N. (1966): Freshwater diatoms from Ghana. - Biol. Skr. Dan. Vid. Selsk. 15 (1): 169 pp.

GASSE, F. (1986): East African diatoms: taxonomy, ecological distribution. - 201 pp., J. Cramer, Berlin and Stuttgart.

Gasse, F. \& TeKaiA, F. (1983): Transfer functions for estimating paleoecological conditions $(\mathrm{pH})$ from East African diatoms. - Hydrobiologia 103: 85-90. doi: 10.1007/ BF00028433.

Gasse, F.; Juggins, S. \& Khelifa, B. (1995): Diatom-based transfer functions for inferring past hydrochemical characteristics of African lakes. - Palaeogeogr. Palaeoclimatol. Palaeoecol. 117: 31-54. doi: 10.1016/0031-0182(94)00122-O.

Gasse, F.; Barker, P.; Gell, P.; Fritz, S. \& Chalie, F. (1997): Diatom-inferred salinity in palaeolakes: an indirect tracer of climate change. - Quat. Sci. Rev. 16: 547-563. doi: 10.1016/S0277-3791(96)00081-9.

GeissLer, U. (1970a): Die Variabilität der Schalenmerkmale bei den Diatomeen. - Nova Hedwigia, 19: 623-773.

GeIsSLER, U. (1970b): Die Schalenmerkmale der Diatomeen. Ursachen ihrer Variabilität und Bedeutung für die Taxonomie. - Nova Hedwigia, Beih. 31: 511-35.

Hustedt, F. (1949): Süsswasser-Diatomeen aus dem AlbertNationalpark in Belgisch-Kongo. - 199 pp., Exploration du Parc National Albert, Mission H. Damas (1935-1936). 
Institut des Parcs Nationaux du Congo Belge, Bruxelles.

Hustedt, F. (1957): Die Diatomeenflora des Flußsystems der Weser im Gebiet der Hansestadt Bremen. - Abh. Naturwiss. Ver. Bremen 34: 181-440.

Kling, H.; Mugidde, R. \& Hecky, R. (2001): Recent changes in the phytoplankton community of Lake Victoria in response to eutrophication. - In: MunAwar, M. \& Hecky, R. (eds): The great lakes of the world (GLOW): food-web, health and integrity. - pp. 47-65. Backhuys, Leiden, The Netherlands

Krammer, K. \& LANGe-Bertalot, H. (1988): Bacillariophyceae: Teil 2: Bacillariaceae, Epithemiaceae, Surirellaceae. - In: Ettl, H.; Gerloff, J.; Heynig, H. \& Mollenhauer, D. (eds): Süsswasserflora von Mitteleuropa, Band 2/2. -596 pp. VEB Gustav Fischer, Jena.

Krstić, S.; Zech, W.; Obreht, I.; SvirČEv, Z. \& Marković, S. (2012): Late Quaternary environmental changes in Helambu Himal, Central Nepal, recorded in the diatom flora assemblage composition and geochemistry of Lake Panch Pokhari. - J. Paleolimnol. 47: 113-124.

Lamb, H.; Kebede, S.; Leng, M.; Ricketts, D.; Telford, R. \& UMER, M. (2002): Origin and isotopic composition of aragonite laminae in an Ethiopian crater lake. - In: OdAdA, E. \& Olago, D. (eds): The East African Great Lakes: Limnology, Palaeolimnology and Biodiversity. - pp. 487-508. Springer, Dordrecht. doi: 10.1007/0-306-48201-0 20.

Legesse, D.; Gasse, F.; Radakovitch, O.; Vallet-Coulomb, C.; Bonnefille, R.; Verschuren, D.; Gibert, E. \& BARKER, P. (2002): Environmental changes in a tropical lake (Lake Abiyata, Ethiopia) during recent centuries. - Palaeogeogr. Palaeoclimatol. Palaeoecol. 187: 233-258.

Lemma, B. (2009): Observations on the relations of some physico-chemical features and DVM of Paradiaptomus africanus in Lakes Bishoftu-Guda and Hora-Arsedi, Bishoftu, Ethiopia. - Limnologica 39: 230-243.

Mann, D.G. (1978): Studies in the Nitzschiaceae (Bacillariophyta). - 2 vols, Ph.D. Dissertation. University of Bristol. Available online at https://rbg-web2.rbge.org.uk/algae/ publications mann thesis.html

Mann, D.G. (1986): Nitzschia subgenus Nitzschia (Notes for a monograph of the Bacillariaceae 2). - In: RICARD, M. (ed.), Proceedings of the 8th International Diatom Symposium. - pp. 215-226, O. Koeltz, Koenigstein.

MiLls, K. \& RYvES, D. (2012): Diatom-based models for inferring past water chemistry in western Ugandan crater lakes. - J. Paleolimnol. 48: 383-399. doi: 10.1007/ s10933-012-9609-2.

MiLNE, I. (2007): Climate and environmental change inferred from diatom communities in Lake Challa (KenyaTanzania) [MSc thesis]. - 112 pp., Department of Biology, Queens University, Kingston, Ontario.

Morales, E. \& Hamilton, P. (2002): Seventh NAWQA Taxonomy Workshop on Harmonization of Algal Taxonomy. - Philadelphia, USA.

RichARDSON, J.L. (1968): Diatoms and lake typology in East and Central Africa. - Int. Rev. ges. Hydrobiol. Hydrogr. 53: 299-338.

Rovira, L.; Trobajo, R.; Sato, S.; IbÁÑEz, C. \& Mann, D.G. (2015): Genetic and physiological diversity in the diatom Nitzschia inconspicua. J. Euk. Microbiol. 62: 815-832. doi:10.1111/jeu.12240

Rueden, C.; Schindelin, J.; Hiner, M.; De Zonia, B.; Walter, A.; Arena, E. \& Eliceiri, K. (2017): ImageJ2:
Image J for the next generation of scientific image data. - BMC Bioinformatics 18: 529. doi: 10.1186/ s12859-017-1934-Z.

SARMento, H.; Isumbisho, M. \& Descy, J.-P. (2006): Phytoplankton ecology of Lake Kivu (eastern Africa). - J. Plankton Res. 28: 815-829. doi: 10.1093/plankt/fbl017.

Schindelin, J.; Arganda-Carreras, I.; Frise, E.; Kaynig, V.; Longair, M.; Pietzsch, T.; Preibisch, S.; Rueden, C.; SaAlfeld, S.; Schmid, B.; Tinevez, J.; White, D.; Hartenstein, V.; Eliceiri, K.; TomancaK, P. \& CArdona, A. (2012): Fiji: an open-source platform for biological-image analysis. - Nature Methods 9: 676-682. doi: 10.1038/nmeth.2019.

Simonsen, R. (1987): Atlas and Catalogue of the Diatom Types of Friedrich Hustedt. -3 vols. J. Cramer, Berlin $\&$ Stuttgart.

Sitoki, L.; KofleR, W. \& RotT, E. (2013): Planktonic needle-shaped Nitzschia species from Lake Victoria, Africa, revisited. - Diatom Res. 28: 165-174. doi: 10.1080/0269249X.2013.765509.

Stager, J.; Cocquyt, C.; Bonnefille, R.; Weyhenmeyer, C. \& Bowerman, N. (2009): A late Holocene paleoclimatic history of Lake Tanganyika, East Africa. - Quat. Res. 72: 47-56. doi: 10.1016/j.yqres.2009.04.003.

Stager, J.; Cumming, B. \& Meeker, L. (1997): A high-resolution 11,400-yr diatom record from Lake Victoria, East Africa. - Quat. Res. 47: 81-89. doi: 10.1006/ QRES.1996.1863.

Stager, J.; Cumming, B. \& Meeker, L. (2003): A 10,000-year high-resolution diatom record from Pilkington Bay, Lake Victoria, East Africa. - Quat. Res. 59: 172-181. doi: 10.1016/S0033-5894(03)00008-5.

TAlling, J. \& TAlling, I. (1965): The chemical composition of African lake waters. - Int. Rev. ges. Hydrobiol. Hydrogr. 50: 421-463.

TAYlor, J.; Harding, W. \& Archibald, C. (2007): An illustrated guide to some common diatom species from South Africa. - Pretoria.

Trobajo, R.; Cox, E. \& Quintana, X. (2004): The effect of some environmental variables on the morphology of Nitzschia frustulum (Bacillariophyta), in relation to its use as a bioindicator. - Nova Hedwigia 79: 433-45

Trobajo, R.; Mann, D.G.; Chepurnov, V.; Clavero, E. \& Cox, E.J. (2006): Taxonomy, life cycle, and auxosporulation of Nitzschia fonticola (Bacillariophyta). - J. Phycol. 42: 1353-1372. doi: 10.1111/j.1529-8817.2006.00291.x.

Trobajo, R.; Clavero, E.; Chepurnov, V.A.; SabBe, K.; Mann, D.G.; IsHIHARA, S. \& Cox, E.J. (2009): Morphological, genetic and mating diversity within the widespread bioindicator Nitzschia palea (Bacillariophyceae). Phycologia 48: 443-459. doi: 10.2216/08-69.1

Trobajo, R.; Rovira, L.; Mann, D.G. \& Cox, E.J. (2011): Effects of salinity on growth and on valve morphology of five estuarine diatoms. - Phycol. Res. 59: 83-90. doi: 10.1111/j.1440-1835.2010.00603.x

Trobajo, R.; Mann, D.G. \& Cox, E.J. (2012): Studies on the type material of Nitzschia abbreviata (Bacillariophyta). - Nova Hedwigia, Beih. 141: 185-200.

Trobajo, R.; Rovira, L.; Ector, L.; Wetzel, C.; Kelly, M. \& MANN, D.G. (2013): Morphology and identity of some ecologically important small Nitzschia species. - Diatom Res. 28: 37-59. doi: 10.1080/0269249X.2012.734531.

Van Dam, H.; Mertens, A. \& SinKeldam, J. (1994): A coded checklist and ecological indicator values of freshwater diatoms from The Netherlands. - Neth. J. Aquat. Ecol. 
28: 117-133. doi: 10.1007/BF02334251.

Wolff, C.; Kristen-Jenny, I.; Schettler, G.; Plessen, B.; Meyer, H.; Dulski, P.; Naumann, R.; Brauer, A.; Verschuren, D. \& Haug, G. (2014): Modern seasonality in Lake Challa (Kenya/Tanzania) and its sedimentary documentation in recent lake sediments. - Limnol. Oceanogr. 59: 1621-1636. doi: 10.4319/ lo.2014.59.5.1621.

VERSCHUREN, D. (2003): Lake-based climate reconstruction in Africa: progress and challenges. - Hydrobiologia 500: 315-330. doi: 10.1023/A:1024686229778.

WoOd, R. \& TALLING, J. (1988): Chemical and algal relationships in a salinity series of Ethiopian inland waters. Hydrobiologia 158: 29-67. doi: 10.1007/BF00026266.

Wood, R.; Prosser, M. \& Baxter, R. (1976): The seasonal pattern of thermal characteristics of four of the Bishoftu Crater Lakes, Ethiopia. - Freshw. Biol. 6: 519-530. doi: 10.1111/j.1365-2427.1976.tb01643.x.

Wood, R.; Baxter, R. \& Prosser, V. (1984): Seasonal and comparative aspects of chemical stratification in some tropical crater lakes Ethiopia. - Freshw. Biol. 14: 551-573. doi: 10.1111/j.1365-2427.1984.tb00176.x.

Supplementary material

the following supplementary material is available for this article:

Figs S1-S8. Nitzschia fenestralis and N. obsoleta, extra SEM micrographs.

Fig. S9. Context photograph for the holotype of $N$. fenestralis. Table S1. AMS radiocarbon dates for the Lake Babogaya core

This material is available as part of the online article (http:// fottea.czechphycology.cz/contents)

(C) Czech Phycological Society (2020)

Received June 5, 2019

Accepted September 9, 2019 